\title{
A Short Description of Social Networking Websites And Its Uses
}

\author{
Ateeq Ahmad \\ Department of Computer science \& Engineering \\ Singhania University \\ Pacheri Bari, Disst. Jhunjhunu (Rajasthan)-333515, India \\ Email:atq_yas@rediffmail.com
}

\begin{abstract}
Now days the use of the Internet for social networking is a popular method among youngsters. The use of collaborative technologies and Social Networking Site leads to instant online community in which people communicate rapidly and conveniently with each other. The basic aim of this research paper is to find out the kinds of social network are commonly using by the people.
\end{abstract}

Keywords-Social Network, kinds, Definition, Social Networking web sites, Growth.

\section{INTRODUCTION}

A web site that provides a social community for people interested in a particular subject or interest together. Members create there own online profile with data, pictures, and any other information. They communicate with each other by voice, chat, instant message, videoconferencing, and the service typically provides a way for members to connect by making connections through individuals is known as Social networking. Now days there are many web sites dedicated to the Social Networking, some popular websites are. Facebook, Orkut, Twitter, Bebo, Myspace, Friendster, hi5, and Bharatstudent are very commonly used by the people. These websites are also known as communities network sites. Social networking websites function like an online community of internet users. Depending on the website in question, many of these online community members share common interests in hobbies, discussion. Once you access to a social networking website you can begin to socialize. This socialization may include reading the profile pages of other members and possibly even contacting them.

\section{DEFINITION}

Boyd and Ellison (2007) define social network services as web-based services which allow individuals to Construct a public or semipublic profile within a bounded system, Communicate with other users; and View the pages and details provided by other users within the system. The social networking websites have evolved as a combination of personalized media experience, within social context of participation. The practices that differentiate social networking sites from other types of computer-mediated communication are uses of profiles, friends and comments or testimonials profiles are publicly viewed, friends are publicly articulated, and comments are publicly visible.
Users who join Social networking websites are required to make a profile of themselves by filling up a form. After filling up the forms, users are supposed to give out information about their personality attributes and personal appearances. Some social networking websites require photos but most of them will give details about one's age, preference, likes and dislikes. Some social networking websites like Facebook allow users to customize their profiles by adding multimedia content. (Geroimenko \& Chen, 2007)

\section{CHARACTERISTICS OF SOCIAL NETWORKING SITES}

Social networking websites provide rich information about the person and his network, which can be utilized for various business purposes. Some of the main characteristics of social networking sites are:

- They act as a resource for advertisers to promote their brands through word-of-mouth to targeted customers.

- They provide a base for a new teacher-student relationship with more interactive sessions online.

- They promote the use of embedded advertisements in online videos.

- They provide a platform for new artists to show their profile.

\section{OBJECTIVE}

The basic objective of this research is to analysis about the awareness and frequency regarding the use of social networking websites.

\section{History OF SOCIAL NETWORKING WEBsites}

The first social networking websites was launched in the year 1997 Sixdegrees.com. This company was the first of its kind; it allowed user to list their profiles, provide a list of friends and then contact them. However, the Company did not do very well as it eventually closed three years later. The reason for this was that many people using the internet at that time had not formed many social networks hence there was little room for maneuver. It should be noted that there were also other elements that hinted at Social network websites. For instance, dating sites required users to give their profiles but they could not share other people's websites. Additionally, 
there were some websites that would link former school mates but the lists could not be shared with others. (Cassidy, 2006)

After this there was the creation of Live Journal in the year 1999. It was created in order to facilitate one way exchanges of journals between friends. Another company in Korea called CY world added some social networking features in the year 2001. This was then followed by Lunar Storm in Sweden during the same year. They include things like diary pages and friends lists. Additionally, Ryze.com also established itself in the market. It was created with the purpose of linking business men within San Francisco. The Company was under the management of Friendster, LinkedIn, Tribe.net and Ryze. The latter company was the least successful among all others. However, Tribe.net specialized in the business world but Friendster initially did well; this did not last for long. (Cohen, 2003)

\section{Social Networking Websites that ARE COMMONLY USED BY THE PEOPLE}

The most significant Social networking websites commonly used by the people especially by the youngster like, Friendster, Myspace, Facebook, Downlink, Ryze, SixDegrees, Hi 5, LinkedIn, Orkut, Flicker, YouTube, Reddit, Twitter, FriendFeed, BharatStudent and Floper.

\section{A. Friendster}

Friendster began its operations in the year 2002. It was a brother company to Ryze but was designed to deal with the social aspect of their market. The company was like a dating service, however, match making was not done in the typical way where strangers met. Instead, friends would propose which individuals are most compatible with one another. At first, there was an exponential growth of the Comply. This was especially after introduction of network for gay men and increase in number of bloggers. The latter would usually tell their friends about the advantages of social networking through Friendster and this led to further expansion. However, Friendster had established a market base in one small community. After their subscribers reached overwhelming numbers, the company could no longer cope with the demand. There were numerous complaints about the way their servers were handled because subscribers would experience communication breakdowns. As if this was not enough, social networks in the real world were not doing well; some people would find themselves dating their bosses or former classmates since the virtual community created by the company was rather small. The Company also started limiting the level of connection between enthusiastic users. (Boyd, 2004)

\section{B. MySpace}

By 2003, there were numerous companies formed with the purpose of providing social networking service. However, most of them did not attract too much attention especially in the US market. For instance, LinkedIn and Xing were formed for business persons while services like MyChurch, Dogster and Couchsurfing were formed for social services. Other companies that had been engaging in other services started offering social networking services. For instance, the You Tube and Last. FM was initially formed to facilitate video and music sharing respectively. However, the started adopted social networking services. (Backstrom et al, 2006)

\section{Facebook}

This social networking service was introduced with the purpose of linking friends in Harvard University in 2004. Thereafter, the company expanded to other universities then colleges. Eventually, they invited corporate communities. But this does not mean that profiles would be interchanged at will. There are lots of restrictions between friends who join the universities social network because they have to have the .edu address. Additionally, those joining corporate network must also have the .com attachment. This company prides itself in their ability to maintain privacy and niche communities and have been instrumental in learning institutions. (Charnigo \& Barnett-Ellis, 2007)

\section{Downelink}

This website was founded in 2004 for the lesbian, gay, bisexual, and transgender community. Some features include social networking, weblogs, internal emails, a bulletin board, DowneLife and in the future, a chat.

\section{E. Ryze}

The first of the online social networking sites, Adrian Scotts founded Rzye as a business-oriented online community in 2001.Business people can expand their business networks by meeting new people and join business groups, called Networks, through industries, interests, and geographic areas.

\section{F. SixDegrees}

Six Degrees was launched in 1997 and was the first modern social network. It allowed users to create a profile and to become friends with other users. While the site is no longer functional, at one time it was actually quite popular and had around a million of members.

\section{G. $\mathrm{Hi5}$}

Hi5 is established in 2003 and currently boasting more than 60 million active members according to their own claims. Users can set their profiles to be seen only by their network members. While Hi5 is not particularly popular in the U.S., it has a large user base in parts of Asia, Latin America and Central Africa.

\section{H. LinkedIn}

LinkedIn was founded in 2003 and was one of the first mainstream social networks devoted to business. Originally, LinkedIn allowed users to post a profile and to interact through private messaging.

\section{Orkut}

Launched in January 2004, is Goggle's social network, and while it's not particularly popular in the U.S., it's very popular in Brazil and India, with more than 65 million users. Orkut lets users share media, status updates, and communicate through IM. 


\section{J. Flickr}

Flickr has become a social network in its own right in recent years. They claim to host more than 3.6 billion images as of June 2009. Flickr also has groups, photo pools, and allows users to create profiles, add friends, and organize images and video.

\section{K. YouTube}

YouTube was the first major video hosting and sharing site, launched in 2005. YouTube now allows users to upload HD videos and recently launched a service to provide TV shows and movies under license from their copyright holders.

\section{Reddit}

Reddit is another social news site founded in 2005. Reddit operates in a similar fashion to other.

\section{Twitter}

Twitter was founded in 2006 and gained a lot of popularity during the 2007. Status updates have become the new norm in social networking.

\section{N. FriendFeed}

Friend Feed launched in 2007 and was recently purchased by Facebook, allow you to integrate most of your online activities in one place. It's also a social network in its own right, with the ability to create friends lists, post and updates.

\section{O. BharatStudent}

Bharatstudent is a social utility that brings together all the young Indians living across the globe. It is for every Young Indian who is a student or a non-student, fresh graduate, a working professional or an Entrepreneur, and is focused on providing comprehensive solutions for any personal and professional issues.

\section{P. Fropper}

Fropper is ALL about meeting people, making new friends $\&$ having fun with photos, videos, games \& blogs! Come, become a part of the 4 Million strong Fropper communities.

\section{Growth OF Social Networking Websites.}

Now day's Social networking popularity is increasing rapidly around the world. Social networking behemoth MySpace.com attracted more than 114 million global visitors age 15 and older in June 2007, representing a 72-percent increase versus year ago. Facebook.com experienced even stronger growth during that same time frame, jumping 270 percent to 52.2 million visitors. Bebo.com (up 172 percent to 18.2 million visitors) and Tagged.com (up 774 percent to 13.2 million visitors) also increased by orders of magnitude. (ComScore)

\section{A. Worldwide Growth of Selected social Networking Sites between June 2006 and June 2007}

During the past year, social networking has really taken off globally, Literally hundreds of millions of people around the world are visiting social networking sites each month and many are doing so on a daily basis(Bob Ivins) see table I.
TABLE I. ANLYSIS OF SOCIAL NETWORKING SITES

\begin{tabular}{|l|c|c|c|}
\hline \multirow{2}{*}{$\begin{array}{l}\text { Social Networking sites } \\
\text { Worldwide }\end{array}$} & \multicolumn{3}{|c|}{ Growth of Social Networking Sites } \\
\cline { 2 - 4 } & June-2006 & June-2007 & $\begin{array}{c}\text { Percent } \\
\text { Change }\end{array}$ \\
\hline MySpace & 66,401 & 114,147 & 72 \\
\hline FaceBook & 14,083 & 52,167 & 270 \\
\hline Hi5 & 18,098 & 28,174 & 56 \\
\hline Friendster & 14,917 & 24,675 & 65 \\
\hline Orkut & 13,588 & 24,120 & 78 \\
\hline Bebo & 6,694 & 18,200 & 172 \\
\hline Tagged & 1,506 & 13,167 & 774 \\
\hline
\end{tabular}

\section{B. Worldwide Growth of Selected social Networking Sites} between June 2007 and June 2008

During the past year, many of the top social networking sites have demonstrated rapid growth in their global user bases. Facebook.com, which took over the global lead among social networking sites in April 2008, has made a concerted effort to become more culturally relevant in markets outside the U.S. Its introduction of natural language interfaces in several markets has helped propel the site to 153 percent growth during the past year. Meanwhile, the emphasis Hi5.com has put on its fullscale localization strategy has helped the site double its visitor base to more than 56 million. Other social networking sites, including Friendster.com (up 50 percent), Orkut (up 41 percent), and Bebo.com (up 32 percent) have demonstrated particularly strong growth on a global basis. See table II.

TABLE II. ANLYSIS OF SOCIAL NETWORKING SITES

\begin{tabular}{|l|c|c|c|}
\hline \multirow{2}{*}{$\begin{array}{l}\text { Social Networking sites } \\
\text { Worldwide }\end{array}$} & \multicolumn{3}{|c|}{ Growth of Social Networking Sites } \\
\cline { 2 - 4 } & June-2007 & June-2008 & $\begin{array}{c}\text { Percent } \\
\text { Change }\end{array}$ \\
\hline Asia Pacific & 162,738 & 200,555 & 23 \\
\hline Europe & 122,527 & 165,256 & 35 \\
\hline North America & 120,848 & 131,255 & 9 \\
\hline Latin America & 40,098 & 53,248 & 33 \\
\hline Middle East - Africa & 18,226 & 30,197 & 66 \\
\hline
\end{tabular}

C. Worldwide Growth of Selected social Networking Sites between July 2009 and July 2010

Social Networking sites in India, that Facebook.com grabbed the number one ranking in the category for the first time in July with 20.9 million visitors, up 179 percent versus year ago. The social networking phenomenon continues to gain steam worldwide, and India represents one of the fastest growing markets at the moment, "Though Facebook has tripled its audience in the past year to pace the growth for the category, several other social networking sites have posted their own sizeable gains." (Will Hodgman)See table III. 
More than 33 million Internet users age 15 and older in India visited social networking sites in July, representing 84 percent of the total Internet audience. India now ranks as the seventh largest market worldwide for social networking, after the U.S., China, Germany, Russian Federation, Brazil and the U.K. The total Indian social networking audience grew 43 percent in the past year, more than tripling the rate of growth of the total Internet audience in India.

TABLE III. ANLYSIS OF SOCIAL NETWORKING SITES

\begin{tabular}{|l|c|c|c|}
\hline \multirow{2}{*}{$\begin{array}{l}\text { Social Networking sites } \\
\text { Worldwide }\end{array}$} & \multicolumn{3}{|c|}{ Growth of Social Networking Sites } \\
\cline { 2 - 4 } & July-2009 & July-2010 & $\begin{array}{c}\text { Percent } \\
\text { Change }\end{array}$ \\
\hline United States & 131,088 & 174,429 & 33 \\
\hline China & N/A & 97,151 & N/A \\
\hline Germany & 25,743 & 37938 & 47 \\
\hline Russian Federation & 20,245 & 35,306 & 74 \\
\hline Brazil & 23,966 & 35,221 & 47 \\
\hline United Kingdom & 30,587 & 35,153 & 15 \\
\hline India & 23,255 & 33,158 & 43 \\
\hline France & 25,121 & 32,744 & 30 \\
\hline Japan & 23,691 & 31,957 & 35 \\
\hline South Korea & 15,910 & 24,962 & 57 \\
\hline
\end{tabular}

\section{CONCLUSTION}

Social networking websites is also one of the social media tools which can be used as a tool in education industry to generate on line traffic and a pipe line for new entrants. The use of these websites is growing rapidly, while others traditional online is on the decrease. Social network user numbers are staggering, vastly increasing the exposure potential to education industry through advertising industry.

Social network offers people great convenience for social networking. It allows people to keep in touch with friends, and with old friends, meet new people, and even conduct business meeting online. You can find people with similar interests as you and get to know them better, even if they are in a different country. Every day people are joining the Social Network. And the growth and uses of social networking are increasing, all over the World.

\section{REFERENCES}

[1] Budden C B, Anthony J F, Budden M C and Jones M A (2007), "Managing the Evolution of a Revolution: Marketing Implications of Internet Media Usage Among College Students", College Teaching Methods and Styles Journal, Vol. 3, No. 3, pp. 5-10.

[2] Danielle De Lange, Filip Agneessens and Hans Waege (2004), "Asking Social Network Questions: A Quality Assessment of Different Measures", Metodoloki zvezki, Vol. 1, No. 2, pp. 351-378.

[3] David Marmaros and Bruce Sacerdote (2002), "Peer and Social Networks in Job Search", European Economic Review, Vol. 46, Nos. 4 and 5, pp. 870-879.

[4] Feng Fu, Lianghuan Liu and Long Wang (2007), "Empirical Analysis of Online Social Networks in the Age of Web 2.0", Physica A: Statistical Mechanics and its Applications, Vol. 387, Nos. 2 and 3, pp. 675-684.
[5] Kautz H, Selman B and Shah M (1997), "Referral Web: Combining Social Net Works and Collaboration Filtering", Communication of the ACM, Vol. 40, No. 3, pp. 63-65.

[6] Mark Pendergast and Stephen C Hayne (1999), "Groupware and Social Networks: Will Life Ever Be the Same Again?", Information and Software Technology, Vol. 41, No. 6, pp. 311-318.

[7] Mayer Adalbert and Puller Steven L (2008), "The Old Boy (and Girl) Network: Social Network Formation on University Campuses", Journal of Public Economics, Vol. 92, Nos. 1 and 2, pp. 329-347.

[8] Reid Bate and Samer Khasawneh (2007), "Self-Efficacy and College Student's Perceptions and Use of Online Learning Systems", Computers in Human Behavior, Vol. 23, No. 1, pp. 175-191.

[9] Sorokou C F and Weissbrod C S (2005), "Men and Women's Attachment and Contact Patterns with Parents During the First Year of College", Journal of Youth and Adolescence, Vol. 34, No. 3, pp. 221-228.

[10] Boyd Danah and Ellison Nicole (2007), "Social Network Sites: Definition, History and Scholarship", Journal of Computer-Mediated Communication, Vol. 13, No. 1.

[11] Boyd Danah (2007), "Why Youth (Heart) "Social Network Sites: The Role of Networked Publics in Teenage Social Life", MacArthur Foundation Series on Digital Learning-Youth, Identity and Digital Media Volume, David Buckingham (Ed.), MIT Press, Cambridge, MA.

[12] Madhavan N (2007), "India Gets More Net Cool", Hindustan Times, July 6, http://www.hindustantimes.com

[13] Cotriss, David (2008-05-29). "Where are they now: Theglobe.com". The Industry Standard.

[14] Romm-Livermore, C, \& setzekorn, K. (2008). Social Networking communities and E-Dating Services: Concepts and Implications. IGI Global. P.271

[15] Knapp, E, (2006). A Parent's Guide to Myspace. DayDream Publishers. ISBN 1-4196-4146-8.

[16] Acquisti, A, \& Gross, R (2006): Imagined communities: Awareness, information sharing, and privacy on the Facebook: Cambridge, UK: Robinson College

[17] Backstrom, L et al (2006): Group formation in large social networks: Membership, growth, and evolution, pp. 44-54, New York ACM Press.

[18] Boyd, D. (2004): Friendster and publicly articulated social networks. Proceeding of ACM

[19] Cassidy, J, (2006): Me media: How hanging out on the Internet Became big Business, The new Yorker, 82,13,50

[20] Charnigo, L \& Barnett-Ellis, p. (2007): Checking out Facebook.com: The impact of a digital trend on academic libraries; Information Technology and Libraries, 26,1,23.

[21] Choi, H (2006): Living in Cyworld: Contextualising CyTies in south Korea, pp. 173-186, New York Peter Lang.

[22] Cohen, R. (2003): Livewire: Web sites try to make Internet dating less creepy, Reuters, retrieved from http://asia.reuters.com Accessed $01 \mathrm{Feb}$ 2011

[23] ComScore (2007): Social networking goes global. Reston, http://www.comscore.com Accessed 01 Feb 2011

[24] Cameron Chapman(2009)History and evolution of social media Retrieved from http://www.webdesignerdepot.com

[25] http://wikipedia.com Accessed 01 Feb 2011.

[26] Worldwide social networking websites(ComScore) http://www.comscore.com Accessed 01 Feb 2011

[27] Geroimenko, V. \& Chen, C. (2007): "Visualizing the Semantic Web", pp. 229-242, Berlin: Springer.

[28] Shahjahan S. (2004), "Research Methods for Management", Jacco Publishing House

[29] Cooper Donald R. and Shindler Panda S (2003), "Business Research Methods", Tata McGraw -Hill Co. Ltd., New Delhi.

[30] Shah Kruti and D'Souza Alan (2009), "Advertising \& Promotions: An IMC perspective", Tata McGraw -Hill Publishing Company Limited, New Delhi. 
[31] Paneeerselvam R. (2004), "Research Methodology", Prentice Hall of India Pvt. Ltd., New Delhi.

[32] Opie Clive, (June 2004), "Doing Educational Research- A Guide for First Time Researchers", Sage Publications, New Delhi,

[33] Kothari C.R. (2005), "Research Methodology: Methods and Techniques", India, and New Age International Publisher.

Cooper Donald R. and Shindler Panda S (2003), "Business Research Methods", Tata McGraw -Hill Co. Ltd., New Delhi.

\section{AUTHOR PROFILE}

Ateeq Ahmad received the Master degree in computer science in year 2003.

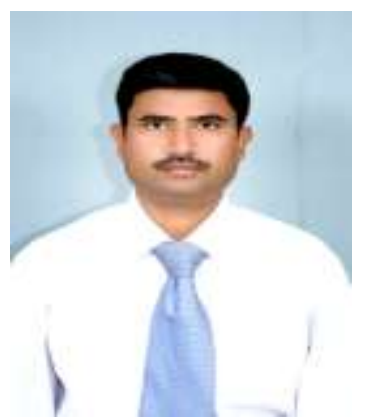

$\mathrm{He}$ has a $\mathrm{PhD}$ student in Department of Computer science \& Engineering Singhania University, Rajasthan India. His research interests include Computer networks, Social Network, Network Security, and Web development. 